\title{
Intestinal mucosa development and blood profile of broiler chickens administered bovine testicular fluid
}

\author{
Ewuola E. O., Olujimi A. T.*, Oyebanjo M. O. and Taiwo T. F. \\ Animal Physiology and Bioclimatology Unit, Department of Animal Science, University of Ibadan, Ibadan, Nigeria. \\ *Corresponding author: Email: olujimitimothy15@gmail.com; Tel: +234 8033719411. \\ Copyright (C) 2021 Ewuola et al. This article remains permanently open access under the terms of the Creative Commons Attribution License 4.0, \\ which permits unrestricted use, distribution, and reproduction in any medium, provided the original work is properly cited.
}

Received 26th April, 2021; Accepted 28th May, 2021

\begin{abstract}
A seven-week experiment was carried out to determine the effect of bovine testicular fluid on intestinal mucosa development, haematological variables and serum biochemical indices of broiler chickens. A total of 125 unsexed day-old Abor acre chicks were randomly allotted into five treatments, with each treatment having five replicates with five birds per replicate. They were fed a commercial broiler diet for seven weeks of the experiment. Different concentrations of the bovine testicular fluid per liter of drinking water were offered to the experimental birds at free choice, the birds in treatment 1 served as the control and they were offered ordinary drinking water while birds in treatments 2, 3, 4 and 5 were offered 25, 50, 75 and $100 \mathrm{ml}$ of bovine testicular fluid per liter of water, respectively. The feed and water intake of each bird were measured on daily basis, while the average weight of the birds was measured on weekly basis. On day 21 and 49, blood samples were collected from the birds to determine the haematological and serum biochemical indices. Two birds from each replicate were sacrificed on day 49 and sample of ileum were taken for intestinal mucosal examination after processed into permanent slides. The results of the blood indices obtained on days 21 and 49 indicated that the blood parameters were within the normal physiological range for chickens and without evidence of organ damage. The villus height, villus width, crypt depth, crypt height, and mucosa thickness showed that the bovine testicular fluid increased the absorptive capacity of the intestinal mucosa surface area and their growth. It is recommended that bovine testicular fluid at $100 \mathrm{ml} / \mathrm{L}$ improved intestinal mucosa development and absorption capacity of broiler chickens and enhanced their growth without deleterious effect on their health status.
\end{abstract}

Keywords: Bovine testicular fluid, broiler chickens, haematology, serum biochemistry.

\section{INTRODUCTION}

The use of antibiotics as a growth promoter in the livestock industry has been found as a major threat to the commercial poultry industry and human health. Evidence has shown that the residual effect may compromise the health status of the end users (humans). The consequences of which led to the recent ban on the use of such synthetic growth promoter in the production of livestock in developed countries of the world (Hughes and Heritage, 2004). The implication of the ban in the use of antibiotic growth-promoters has led to the manipulation of feed ingredients, by the feed mill industry in order to improve and balance up their profit margin (Adejinmi et al., 2015). The implication of which has led to the poor turnover of broiler chickens and low consumption of adequate animal protein by the human population of the country. Poultry production is the best livestock sector that can easily make available sufficient animal protein needed to survive and maintain the human body growth and development. This is because it is very cheap, affordable, and has a short gestation period compared to sheep, goat and cattle. To provide and improve the availability and the daily consumption of animal protein by the increasing human population of Nigeria, there is a need to focus our research on the growth-promoting potentials of bovine testicular fluid, which can be obtained from the testes of a matured bull; a waste product readily available in abattoirs. This natural growth-promoter could be used to replace antibiotic growth-promoter in broiler chicken production, as it contains crude testosterone - a growth-enhancing additive. 
The bovine testicular fluid, which consists mainly of testosterone as the chief hormone (Egbunike et al., 2008, Adejinmi et al., 2015; Ewuola and Olujimi, 2019), could improve the growth performance and welfare of broiler chickens by synergizing with other hormones to enhance the feed efficiency thereby improve weight gain (William et al., 1992; Annamaria, 2012; Ewuola and Olujimi 2019), and also improve the performance of various organs and system such as digestive system and the heart function (Muthusamy et al., 2011). According to Kitt et al. (2001), villi and the crypt are the major region within the small intestine in which most of the feed digestion and absorption of the feed nutrients takes place. However, the implication of testicular fluid on the blood profile when used as a growth promoter in broiler chickens and the mechanism by which the feed nutrients is been absorbed by the villus to influence growth development are not clear. Therefore, this study was designed to examine the effects of the bovine testicular fluid on the blood profile and intestinal mucosa development in broiler chickens.

\section{MATERIALS AND METHODS}

\section{Experimental site}

The experiment was carried out at the Poultry Research Unit of the Teaching and Research Farm, University of Ibadan, Ibadan, Oyo State, Nigeria.

\section{Preparation of the bovine testicular fluid}

Testicular fluid was obtained from bulls testes via extraction and centrifugation. Fresh bull testes from healthy bulls were obtained from a reputable abattoir in Ibadan. The tunica albuginea of the testes was removed and the testis was crushed. The crushed testes were homogenized in a dilution of $30 \mathrm{ml}$ of water per gram of testis. An aqueous homogenate was obtained afterwards. The aqueous homogenate was centrifuged at $1,500 \mathrm{rpm}$ (revolution per minute) for 5 minutes (Ewuola and Olujimi, 2019). The result was a testicular fluid (containing crude testosterone). The crude testosterone extract in form of testicular fluid was included in the bird's water at graded levels. The testicular fluid was stored in the refrigerator at $4^{\circ} \mathrm{C}$ until when needed every day.

\section{Experimental design and procedure}

A total number of 125 unsexed day-old chicks (Abor acre) were used for this study. The birds were randomly distributed into 5 treatments, each with 5 replicates, and 5 chicks per replicate. The birds were brooded on wood shavings and fed on a commercial broiler starter diet, containing $22.8 \%$ crude protein and $3035.39 \mathrm{kcal} / \mathrm{kg}$ metabolizable energy, for three weeks; and, finisher diet, containing $20.7 \%$ crude protein and $2834.80 \mathrm{kcal} / \mathrm{kg}$ metabolizable energy, for four weeks. The birds in the treatment one, which was the control were offered only ordinary drinking water while the treatments 2, 3, 4 and 5 birds were offered 25, 50, 75 and $100 \mathrm{ml}$ of the bovine testicular fluid per liter of the drinking water, respectively at free choice for the seven weeks of the study. The feed intake and water intake of the birds were recorded on daily basis, while all the necessary vaccinations and medication schedule were done as recommended for the strains of broiler chickens used in this study. The completely randomized design was adopted in distributing the birds into experimental treatments.

\section{Haematological and serological characteristics of the experimental birds}

The blood samples were collected into two vials from each of the 5 treatments group per replicate. The birds were bled by the jugular vein using hypodermic needles with a syringe. One vial contained ethylene diamine-tetra-acetic acid as an anti-coagulant for haematological assessment, while the other vial for serum collection had no anticoagulant for the serum analysis of the blood sample.

\section{Determination of haematological parameters}

The haematological parameters assessed include; packed cell volume, white blood cell, red blood cell, haemoglobin, platelets, blood constants, as described in Ewuola and Egbunike (2008).

\section{Determination of serum biochemical parameters}

The serum biochemical parameters assessed include; total protein, cholesterol, globulin, albumin, albumin/globulin ratio, creatinine, alanine amino transferase, aspartate amino transferase and alkaline phosphatase, as described by Ewuola and Egbunike (2008).

\section{Intestinal mucosa development assessment}

Samples of ileum were taken for examination from 2 average broilers (randomly selected) from each replicate/treatment $(n=50)$ and processed into permanent slides. Sections of 5 to $8 \mathrm{~mm}$ thickness were taken from each sample and fixed in $10 \%$ formalin solution and absolute alcohol and embedded in paraffin. Sections were cut, mounted on slides and were stained with the HE method as described by Scheuer and Chalk (1986). 
Morphometric examinations of the villus height and width, as well as crypt depth, crypt height, and mucosa thickness were done by light microscopy at a magnification of X400 as described by Djolai et al. (1998) and Ewuola et al. (2011).

\section{Data analysis}

Data were analyzed using ANOVA of SAS (1999).

\section{RESULTS}

\section{Serum biochemical indices of broiler chickens administered bovine testicular fluid at day 21}

The serum biochemical parameters of broiler chickens administered graded levels of bovine testicular fluid at day 21 are presented in Table 1. There was no significant difference in the values obtained for the total protein, albumin, globulin, albumin/globulin ratio, aspartate aminotransferase, alanine amino transferase, alkaline phosphatase, creatinine, and cholesterol across the treatment groups.

\section{Serum biochemical indices of broiler chickens administered bovine testicular fluid at day $\mathbf{4 9}$}

The serum biochemical index of broiler chickens administered graded levels of bovine testicular fluid at day 49 is presented in Table 2. The value obtained for the total protein (TP) in the T5 $(3.52 \mathrm{~g} / \mathrm{dL})$ was found to be significantly $(p<0.05)$ higher than the values obtained for the T4 $(3.22 \mathrm{~g} / \mathrm{dL})$, T3 $(3.14 \mathrm{~g} / \mathrm{dL})$, T2 $(2.98 \mathrm{~g} / \mathrm{dL})$, and T1 $(2.78 \mathrm{~g} / \mathrm{dL})$ across the treatment groups. The group of hens in T5 (32.80 iu/l) had the highest significantly $(p<$ $0.05)$ value of alkaline phosphate (ALP) than T1 $(24.80$ $\mathrm{iu} / \mathrm{l})$, T2 (26.80 iu/l), T3 (27.00 iu/l) and T4 (27.20 iu/l) birds. Though there was no significant difference in the values obtained for the albumin, globulin, aspartate aminotransferase, the alanine amino transferase, creatinine, albumin/globulin ratio and the cholesterol among the treatments.

\section{Haematological parameters of broiler chickens administered bovine testicular fluid at day 21}

The effect of different concentrations of bovine testicular fluid on the haematological parameters of broiler chickens is presented in Table 4. There was no significant difference in the values obtained for the packed cell volume, white blood cell, red blood cell, mean corpuscular volume, mean corpuscular haemoglobin, mean corpuscular haemoglobin concentration, platelets, lymphocytes, monocytes, and eosinophils. The birds administered $75 \mathrm{ml}$ of the bovine testicular fluid had the highest significant $(p>0.05)$ value of the haemoglobin $9.32 \mathrm{~g} / \mathrm{dL}$ than the T1 $(9.04 \mathrm{~g} / \mathrm{dL})$, T4 $(9.00 \mathrm{~g} / \mathrm{dL}), \mathrm{T} 1(9.04 \mathrm{~g} / \mathrm{dL})$ and T5 $(7.83 \mathrm{~g} / \mathrm{dL})$ respectively. The values obtained for the neutrophils show that birds administered with $75 \mathrm{ml}$ of the bovine testicular fluid had the highest value of $34.30 \%$ which was significantly $(p<0.05)$ higher than T1 $(31.00 \%)$, T2 $(31.20 \%)$, T4 $(30.40 \%)$ and T5 (30.29\%) respectively. Likewise, the values obtained for the basophils count did not follow a regular pattern- similar to the reports of Abijo (2017). It was found that the value obtained for the T1 bird (4.20\%) that was administered with $0 \mathrm{ml}$ of the bovine testicular fluid was significantly higher $(p<0.05)$ than the other treatment group $(\mathrm{T} 2=3.00 \%, \mathrm{~T} 4=3.10 \%, \mathrm{~T} 5=3.00 \%$ and $\mathrm{T} 3=2.90 \%$ ) respectively .

\section{Haematological parameters of broiler chickens administered bovine testicular fluid at day $\mathbf{4 9}$}

The effect of different levels of crude testosterone in bovine testicular fluid on the haematological parameters of broiler chickens is presented in Table 4. There was no significant difference in values obtained for packed cell volume, mean corpuscular volume, mean corpuscular haemoglobin, mean corpuscular haemoglobin concentration, haemoglobin, lymphocyte, monocyte, eosinophil, neutrophils and basophils among the treatment groups. The values obtained for white blood cell shows that T4 $\left(16.01 \times 10^{3} / \mathrm{mm}^{\mathrm{s}}\right)$ and T5 $\left(16.26 \times 10^{3} / \mathrm{mm}^{\mathrm{s}}\right)$ was a significantly higher $(\mathrm{p}<0.05)$ than T3 $\left(14.34 \times 10^{3} / \mathrm{mm}^{\mathrm{s}}\right)$, T2 $\left(13.33 \times 10^{3} / \mathrm{mm}^{\mathrm{s}}\right)$ and $\mathrm{T} 1\left(15.61 \times 10^{3} / \mathrm{mm}^{\mathrm{s}}\right)$. The values obtained for platelets shows that T1 $\left(27.56 \times 10^{3} / \mathrm{mm}^{3}\right)$ was significantly higher $(\mathrm{p}<0.05)$ than T5 $\left(19.57 \times 10^{3} / \mathrm{mm}^{3}\right)$, T4 $\left(21.46 \times 10^{3} / \mathrm{mm}^{3}\right)$, T3 $\left(26.11 \times 10^{3} / \mathrm{mm}^{3}\right)$ and T2 (25.24 $\times 10^{3} / \mathrm{mm}^{3}$ ) respectively, while the value obtained for the red blood cells also shows that the T5 $(3.63 \pm 0.03)$ and T4 $(3.54 \pm 0.05)$ had the highest significant $(\mathrm{p}<0.05)$ values compared to T2 $(3.36 \pm 0.11)$, T3 $(3.16 \pm 0.0 .24)$, and T1 $(3.02 \pm 0.23)$ respectively.

\section{The intestinal mucosal assessment of broiler chickens administered different levels of bovine testicular fluid}

The effect of the different concentration of bovine testicular fluid on the ileal mucosa development in broiler chickens is presented in Table 5. There were significant differences $(p<0.05)$ in the mean values obtained for the villus height across the treatments. The birds on T5 $(4966.6 \mu \mathrm{m})$ and T4 $(4952.6 \mu \mathrm{m})$ birds were significantly $(\mathrm{p}<0.05)$ higher than the values obtained for the T3 $(4343.3 \mu \mathrm{m})$, T2 $(4294.2 \mu \mathrm{m})$, and T1 $(4716.2 \mu \mathrm{m})$ birds, respectively. Significant differences $(p<0.05)$ was observed in the values obtained for the villi width as the values obtained ranged from 30.13 to $39.86 \mu \mathrm{m}$ with $\mathrm{T} 5$ birds having higher 
Table 1. Serum biochemical indices of broiler chickens administered bovine testicular fluid at day 21

\begin{tabular}{lcccccc}
\hline Parameter & T1 & T2 & T3 & T4 & T5 & P value \\
\hline Total protein $(\mathrm{g} / \mathrm{dL})$ & $2.58 \pm 0.13$ & $2.68 \pm 0.12$ & $2.70 \pm 0.20$ & $3.08 \pm 0.22$ & $2.70 \pm 0.11$ & 0.28 \\
Albumin $(\mathrm{g} / \mathrm{dL})$ & $0.74 \pm 0.17$ & $0.84 \pm 0.14$ & $0.74 \pm 0.15$ & $1.10 \pm 0.21$ & $0.84 \pm 0.15$ & 0.55 \\
Globulin $(\mathrm{g} / \mathrm{dL})$ & $1.94 \pm 0.08$ & $2.04 \pm 0.17$ & $1.96 \pm 0.07$ & $1.98 \pm 0.09$ & $2.00 \pm 0.05$ & 0.96 \\
A/G Ratio & $0.36 \pm 0.09$ & $0.36 \pm 0.04$ & $0.34 \pm 0.04$ & $0.54 \pm 0.12$ & $0.42 \pm 0.07$ & 0.44 \\
AST (iu/l) & $190.40 \pm 2.27$ & $195.00 \pm 0.63$ & $190.80 \pm 1.85$ & $191.20 \pm 1.46$ & $204.40 \pm 10.60$ & 0.27 \\
ALP (iu/l) & $28.20 \pm 2.80$ & $27.40 \pm 1.50$ & $29.00 \pm 1.30$ & $26.60 \pm 1.08$ & $26.80 \pm 0.86$ & 0.83 \\
ALT (iu/l) & $399.20 \pm 45.74$ & $335.40 \pm 36.74$ & $365.20 \pm 38.52$ & $336.60 \pm 39.06$ & $370.20 \pm 26.71$ & 0.72 \\
Creatinine (mg/dL) & $0.58 \pm 0.04$ & $0.66 \pm 0.04$ & $0.58 \pm 0.05$ & $0.68 \pm 0.06$ & $0.58 \pm 0.04$ & 0.34 \\
Cholesterol $(\mathrm{mg} / \mathrm{dL})$ & $156.00 \pm 12.16$ & $197.00 \pm 24.58$ & $203.60 \pm 20.85$ & $205.20 \pm 24.58$ & $211.80 \pm 17.25$ & 0.30 \\
\hline
\end{tabular}

Different treatments; T1 = control $(0 \mathrm{ml}), \mathrm{T} 2=25 \mathrm{ml}, \mathrm{T} 3=50 \mathrm{ml}, \mathrm{T} 4=75 \mathrm{ml}, \mathrm{T} 5=100 \mathrm{ml}$, AST = aspartate aminotransferase, ALP $=$ alkaline phosphatase, $A L T=$ alanine amino transferase, $A / G$ ratio $=$ Albumin/globulin ratio.

Table 2. Serum biochemical indices of broiler chickens at day 49.

\begin{tabular}{lcccccc}
\hline Parameters & T1 & T2 & T3 & T4 & T5 & SEM \\
\hline Total protein $(\mathrm{g} / \mathrm{dl})$ & $2.78 \pm 0.15^{\mathrm{b}}$ & $2.98 \pm 0.13^{\mathrm{b}}$ & $3.14 \pm 0.14^{\mathrm{ab}}$ & $3.22 \pm 0.14^{\mathrm{ab}}$ & $3.52 \pm 0.24^{\mathrm{a}}$ & 0.05 \\
Albumin $(\mathrm{g} / \mathrm{dL})$ & $0.88 \pm 0.15$ & $0.940 \pm 0.17$ & $1.180 \pm 0.18$ & $1.34 \pm 0.13$ & $1.40 \pm 0.18$ & 0.13 \\
Globulin $(\mathrm{g} / \mathrm{dL})$ & $2.12 \pm 0.18$ & $2.04 \pm 0.04$ & $1.96 \pm 0.07$ & $1.88 \pm 0.07$ & $2.13 \pm 0.07$ & 0.36 \\
A/G Ratio & $0.40 \pm 0.10^{\mathrm{a}}$ & $0.44 \pm 0.10^{\mathrm{ab}}$ & $0.58 \pm 0.11^{\mathrm{ab}}$ & $0.72 \pm 0.08^{\mathrm{a}}$ & $0.64 \pm 0.07^{\mathrm{ab}}$ & 0.13 \\
AST $(\mathrm{iu} / \mathrm{l})$ & $193.60 \pm 6.07^{\mathrm{a}}$ & $195.80 \pm 5.93^{\mathrm{a}}$ & $197.20 \pm 6.00^{\mathrm{a}}$ & $197.60 \pm 12.35^{\mathrm{a}}$ & $209.70 \pm 13.58^{\mathrm{a}}$ & 0.79 \\
ALP $(\mathrm{iu} / \mathrm{l})$ & $24.80 \pm 0.97^{\mathrm{b}}$ & $26.80 \pm 1.32^{\mathrm{b}}$ & $27.00 \pm 1.82^{\mathrm{b}}$ & $27.20 \pm 1.74^{\mathrm{b}}$ & $32.80 \pm 2.24^{\mathrm{a}}$ & 0.03 \\
ALT (iu/l) & $270.00 \pm 25.64^{\mathrm{b}}$ & $300.20 \pm 44.09^{\mathrm{ab}}$ & $306.60 \pm 24.29^{\mathrm{ab}}$ & $333.20 \pm 33.86^{\mathrm{ab}}$ & $384.00 \pm 26.84^{\mathrm{a}}$ & 0.17 \\
Creatinine $(\mathrm{mg} / \mathrm{dL})$ & $0.54 \pm 0.02$ & $0.62 \pm 0.06$ & $0.64 \pm 0.02$ & $0.64 \pm 0.02^{\mathrm{a}}$ & $0.68 \pm 0.10$ & 0.47 \\
Cholesterol $(\mathrm{mg} / \mathrm{dL})$ & $150.80 \pm 7.28$ & $153.00 \pm 6.85$ & $171.20 \pm 19.07$ & $180.40 \pm 20.68$ & $182.60 \pm 23.87$ & 0.56 \\
\hline
\end{tabular}

${ }^{a b}=$ means on the same row with different superscripts are significantly $(p<0.05)$ different. $\mathrm{T} 1=$ control $(0 \mathrm{ml}), \mathrm{T} 2=25 \mathrm{ml}, \mathrm{T} 3=5 \mathrm{ml}, \mathrm{T} 4=75$ $\mathrm{ml}, \mathrm{T} 5=100 \mathrm{ml}, \mathrm{AST}=$ aspartate aminotransferase, $\mathrm{ALP}=$ alkaline phosphatase $\mathrm{ALT}=$ alanine amino transferase, $\mathrm{A} / \mathrm{G}$ ratio $=$ Albumin/globulin ratio.

Table 3. Haematological parameters of broiler chickens administered bovine testicular fluid at day 21.

\begin{tabular}{lcccccc}
\hline Parameters & T1 & T2 & T3 & T4 & T5 & SEM \\
\hline PVC $(\%)$ & $27.00 \pm 1.32$ & $26.20 \pm 0.72$ & $28.20 \pm 0.96$ & $27.30 \pm 0.80$ & $27.20 \pm 0.58$ & 0.71 \\
Hb $(\mathrm{g} / \mathrm{dL})$ & $9.04 \pm 0.48^{\mathrm{ab}}$ & $8.70 \pm 0.26^{\mathrm{ab}}$ & $9.32 \pm 0.35^{\mathrm{a}}$ & $9.00 \pm 0.32^{\mathrm{ab}}$ & $7.83 \pm 0.24^{\mathrm{b}}$ & 0.89 \\
$\mathrm{RBC}\left(\times 10^{6} / \mathrm{mm}^{3}\right)$ & $3.00 \pm 0.23$ & $3.00 \pm 0.11$ & $3.00 \pm 0.24$ & $3.00 \pm 0.05$ & $3.00 \pm 0.03$ & 0.08 \\
WBC $\left(\times 10^{3} / \mathrm{mm}^{\mathrm{s}}\right)$ & $16.19 \pm 367.64$ & $20.22 \pm 1540.42$ & $18.15 \pm 589.75$ & $18.78 \pm 816.46$ & $23.98 \pm 470.63$ & 0.19 \\
$\mathrm{MCV}\left(\mu^{3}\right)$ & $961.4 \pm 68.51$ & $971.6 \pm 58.20$ & $912.6 \pm 51.33$ & $888.2 \pm 38.41$ & $794.7 \pm 148.00$ & 0.57 \\
MCH $(\mu \mu \mathrm{g})$ & $32.02 \pm 2.12$ & $32.12 \pm 1.74$ & $30.02 \pm 1.56$ & $29.33 \pm 1.41$ & $26.42 \pm 4.88$ & 0.55 \\
MCHC $(\%)$ & $33.40 \pm 0.37$ & $33.15 \pm 0.35$ & $32.98 \pm 0.45$ & $32.98 \pm 0.35$ & $29.23 \pm 2.75$ & 0.13 \\
Platelet $\left(\times 10^{3} / \mathrm{mm}^{3}\right)$ & $19.31 \pm 1.07$ & $19.97 \pm 1.92$ & $19.18 \pm 2.20$ & $20.62 \pm 2.01$ & $17.17 \pm 19.99$ & 0.89 \\
Lymphocytes $(\%)$ & $61.60 \pm 1.59$ & $62.40 \pm 1.85$ & $60.40 \pm 2.17$ & $62.80 \pm 2.03$ & $63.10 \pm 1.47$ & 0.43 \\
Neutrophils $(\%)$ & $31.00 \pm 1.67^{\mathrm{ab}}$ & $31.20 \pm 1.93^{\mathrm{ab}}$ & $33.30 \pm 2.26^{\mathrm{a}}$ & $30.40 \pm 1.64^{\mathrm{ab}}$ & $30.29 \pm 1.64^{\mathrm{b}}$ & 0.05 \\
Monocytes $(\%)$ & $3.90 \pm 0.33$ & $3.20 \pm 0.20$ & $3.10 \pm 0.27$ & $3.30 \pm 0.31$ & $3.40 \pm 0.23$ & 0.78 \\
Basophils $(\%)$ & $4.20 \pm 0.47^{\mathrm{a}}$ & $3.00 \pm 0.50^{\mathrm{ab}}$ & $2.90 \pm 0.53^{\mathrm{ab}}$ & $3.10 \pm 0.57^{\mathrm{ab}}$ & $3.00 \pm 0.41^{\mathrm{b}}$ & 0.11 \\
Eosinophils $(\%)$ & $0.20 \pm 0.13$ & $0.30 \pm 0.13$ & $0.30 \pm 0.15$ & $0.40 \pm 0.13$ & $0.40 \pm 0.13$ & 0.69 \\
\hline
\end{tabular}

${ }^{a b}=$ means on the same row with different superscripts are significantly $(\mathrm{p}<0.05)$ different. $\mathrm{T} 1=$ control $(0 \mathrm{ml}), \mathrm{T} 2=25 \mathrm{ml}, \mathrm{T} 3=50 \mathrm{ml}, \mathrm{T} 4=75 \mathrm{ml}, \mathrm{T} 5$ $=100 \mathrm{ml}, \mathrm{CTE}=$ crude testosterone $\mathrm{MCV}=$ mean corpuscular volume, $\mathrm{MCH}=$ mean corpuscular haemoglobin, $\mathrm{MCHC}=$ mean corpuscular haemoglobin concentration, $\mathrm{PCV}=$ packed cell volume, $\mathrm{WBC}=$ white blood cell, $\mathrm{RBC}=$ red blood cell, $\mathrm{Hb}=$ haemoglobin. 
Table 4. Haematological parameters of broiler chickens administered bovine testicular fluid at day 49.

\begin{tabular}{|c|c|c|c|c|c|c|}
\hline Parameters & $\mathrm{T} 1$ & T2 & T3 & T4 & T5 & SEM \\
\hline PCV (\%) & $29.50 \pm 1.32$ & $30.10 \pm 0.72$ & $31.60 \pm 0.96$ & $31.70 \pm 0.81$ & $31.60 \pm 0.58$ & 0.29 \\
\hline $\mathrm{Hb}(\mathrm{g} / \mathrm{dL})$ & $9.42 \pm 0.48$ & $9.65 \pm 0.26$ & $9.70 \pm 0.35$ & $10.33 \pm 0.32$ & $10.05 \pm 0.24$ & 0.36 \\
\hline $\mathrm{RBC}\left(\mathrm{x} 10^{6} / \mathrm{mm}\right)$ & $3.02 \pm 0.23^{b}$ & $3.36 \pm 0.11^{a b}$ & $3.16 \pm 0.0 .24^{\mathrm{ab}}$ & $3.54 \pm 0.05^{a}$ & $3.63 \pm 0.03^{a}$ & 0.36 \\
\hline WBC $\left(\times 10^{3} / \mathrm{mm}^{3}\right)$ & $15.61 \pm 3.67^{\text {ba }}$ & $13.33 \pm 4.87^{c}$ & $14.34 \pm 5.89^{\mathrm{cb}}$ & $16.01 \pm 8.16^{a}$ & $16.26 \pm 4.70^{\mathrm{a}}$ & 0.00 \\
\hline $\operatorname{MCV}\left(\mu^{3}\right)$ & $1017.41 \pm 65.00$ & $901.28 \pm 25.54$ & $1001.88 \pm 87.88$ & $896.78 \pm 21.58$ & $869.78 \pm 15.29$ & 0.17 \\
\hline $\mathrm{MCH}(\mu \mu \mathrm{g})$ & $32.57 \pm 0.49^{a}$ & $32.04 \pm 0.26^{\mathrm{ab}}$ & $32.52 \pm 0.24^{\mathrm{ab}}$ & $32.57 \pm 0.43^{\mathrm{ab}}$ & $32.89 \pm 0.89^{b}$ & 0.79 \\
\hline $\mathrm{MCHC}(\%)$ & $32.52 \pm 2.25$ & $28.85 \pm 0.740 .74$ & $32.51 \pm 2.75$ & $29.18 \pm 0.72$ & $27.71 \pm 0.82$ & 0.16 \\
\hline Platelet $\left(\times 10^{3} / \mathrm{mm}^{3}\right)$ & $27.56 \pm 1.07^{a}$ & $25.24 \pm 1.92^{\mathrm{ab}}$ & $26.11 \pm 2.01^{\mathrm{ab}}$ & $21.46 \pm 2.20^{\mathrm{ab}}$ & $19.57 \pm 1.99^{c}$ & 0.02 \\
\hline Lymphocyte (\%) & $63.90 \pm 1.59$ & $61.80 \pm 1.85$ & $62.00 \pm 2.17$ & $62.50 \pm 2.03$ & $61.30 \pm 1.47$ & 0.74 \\
\hline Neutrophils (\%) & $29.10 \pm 1.67$ & $31.00 \pm 1.93$ & $29.70 \pm 2.26$ & $29.90 \pm 2.26$ & $32.40 \pm 1.64$ & 0.69 \\
\hline Basophils (\%) & $3.20 \pm 0.33$ & $2.80 \pm 0.20$ & $2.90 \pm 0.28$ & $3.10 \pm 0.31$ & $3.10 \pm 0.23$ & 0.84 \\
\hline Eosinophils (\%) & $3.80 \pm 0.47$ & $4.40 \pm 0.50$ & $5.20 \pm 0.53$ & $4.80 \pm 0.57$ & $3.90 \pm 0.41$ & 0.23 \\
\hline Monocyte (\%) & $0.20 \pm 0.13$ & $0.20 \pm 0.13$ & $0.30 \pm 0.15$ & $0.20 \pm 0.13$ & $0.20 \pm 0.13$ & 0.98 \\
\hline
\end{tabular}

${ }^{\mathrm{ab}}=$ means on the same row with different superscripts are significantly different $(\mathrm{p}<0.05)$. T1= (control) $0 \mathrm{ml}, \mathrm{T} 2=25 \mathrm{ml}, \mathrm{T} 3=50 \mathrm{ml}, \mathrm{T} 4=75 \mathrm{ml}, \mathrm{T} 5=$ $100 \mathrm{ml}, \mathrm{CTE}=$ crude testosterone $\mathrm{MCV}=$ mean corpuscular volume, $\mathrm{MCH}=$ mean corpuscular haemoglobin, $\mathrm{MCHC}=$ mean corpuscular haemoglobin concentration, $\mathrm{PCV}=$ packed cell volume, $\mathrm{WBC}=$ white blood cell, $\mathrm{RBC}=$ red blood cell, $\mathrm{Hb}=$ haemoglobin.

Table 5. lleal mucosal development of broiler chickens administered different levels of Bovine testicular fluid.

\begin{tabular}{lcccccc}
\hline Parameters & T1 & T2 & T3 & T4 & T5 & SEM \\
\hline Villi height $(\mu \mathrm{m})$ & $4716.2 \pm 118.85^{\mathrm{ab}}$ & $4294.2 \pm 122.93^{\mathrm{b}}$ & $4343.3 \pm 172.75^{\mathrm{b}}$ & $4952.6 \pm 151.34^{\mathrm{a}}$ & $4966.6 \pm 147.30^{\mathrm{a}}$ & 0.01 \\
Villi width $(\mu \mathrm{m})$ & $415.43 \pm 16.92^{\mathrm{c}}$ & $497.36 \pm 28.57^{\mathrm{b}}$ & $473.07 \pm 26.16^{\mathrm{bc}}$ & $499.57 \pm 22.82^{\mathrm{b}}$ & $591.38 \pm 26.55^{\mathrm{a}}$ & 0.00 \\
Villi density $(\mu \mathrm{m})$ & $31.39 \pm 1.24^{\mathrm{b}}$ & $34.07 \pm 1.59^{\mathrm{b}}$ & $30.13 \pm 1.11^{\mathrm{b}}$ & $30.54 \pm 1.04^{\mathrm{b}}$ & $39.86 \pm 1.43^{\mathrm{a}}$ & 0.00 \\
Cryptal depth $(\mu \mathrm{m})$ & $2343.5 \pm 217.35$ & $2564.6 \pm 91.87$ & $2483.9 \pm 108.42$ & $2244.4 \pm 85.12$ & $2463.6 \pm 94.48$ & 0.44 \\
Cryptal width $(\mu \mathrm{m})$ & $412.30 \pm 21.19$ & $415.21 \pm 20.61$ & $369.72 \pm 22.22$ & $350.58 \pm 20.70$ & $359.17 \pm 20.79$ & 0.08 \\
Mucosal thickness $(\mu \mathrm{m})$ & $7517.3 \pm 147.69^{\mathrm{a}}$ & $7179.8 \pm 132.04^{\mathrm{a}}$ & $7450.6 \pm 191.58^{\mathrm{a}}$ & $6637.7 \pm 236.52^{\mathrm{b}}$ & $6587.6 \pm 226.92^{\mathrm{b}}$ & 0.01 \\
Intestine weight $(\mathrm{g})$ & $12.13 \pm 1.30^{\mathrm{c}}$ & $15.59 \pm 0.62^{\mathrm{b}}$ & $13.69 \pm 0.68^{\mathrm{bc}}$ & $14.15 \pm 12.56^{\mathrm{bc}}$ & $17.98 \pm 0.74^{\mathrm{a}}$ & 0.00 \\
Intestine length $(\mathrm{cm})$ & $256.14 \pm 0.69^{\mathrm{a}}$ & $256.38 \pm 7.632^{\mathrm{b}}$ & $264.13 \pm 4.80^{\mathrm{b}}$ & $262.63 \pm 2.30^{\mathrm{b}}$ & $282 \pm 5.37^{\mathrm{a}}$ & 0.01 \\
\hline
\end{tabular}

${ }^{\mathrm{abc}}=$ means on the same row with different superscripts are significantly $(\mathrm{p}<0.05)$ different. $\mathrm{T} 1=$ control $(0 \mathrm{ml}), \mathrm{T} 2=25 \mathrm{ml}, \mathrm{T} 3=50 \mathrm{ml}, \mathrm{T} 4=75 \mathrm{ml}$, T5 =100

significant values of $39.86 \mu \mathrm{m}$ than the $\mathrm{T} 1(415.43 \mu \mathrm{m})$. The villi density also ranged from 30.13 to $39.86 \mu \mathrm{m}$. This was significantly higher $(\mathrm{p}<0.05)$ in $\mathrm{T} 5(39.86 \mu \mathrm{m})$ than the T1 birds $(31.39 \mu \mathrm{m})$. There was no significant difference in the values obtained for the cryptal depth and the cryptal width among the treatments. There was no significant difference $(p>0.05)$ in the values obtained for the mucosa thickness, but it was observed that the value obtained for the T1 $(7517.3 \mu \mathrm{m})$, T2 $(7179.8 \mu \mathrm{m})$, and T3 $(7450.6 \mu \mathrm{m})$ were higher than that of the T4 $(6637.7 \mu \mathrm{m})$ and T5 $(6587.6 \mu \mathrm{m})$. There was a significant difference $(p<0.05)$ in the values obtained from the intestinal weight, with T5 having the highest value (17.98 g) and T1 $(12.13 \mathrm{~g})$ having the least value. There was a significant difference $(p<0.05)$ in the intestinal length, with T5 having the highest value $(282 \mathrm{~cm})$ followed by T1 $(256.14 \mathrm{~cm})$, T3 $(264.13 \mathrm{~cm})$, T4 $(262.63 \mathrm{~cm})$, T2 $(256.38 \mathrm{~cm})$.

\section{DISCUSSION}

Serum biochemical and haematological parameters are reliable indicators of the health status of animals, and may have important roles in diagnosis, prognosis, as indicators, and treatments of poultry diseases (Olafedehan et al., 2010). Factors affecting serum biochemical parameters are nutrition, season, climate change, sex, age, type of bird, and management system (Bell, 1971; Forlan et al., 1999).

The total protein levels across the treatments increased gradually up to birds that received $75 \mathrm{ml} /$ liter of the bovine testicular fluid, though the observed total protein and albumin were lower than the values reported by Mitruka and Rawnsley (1977). This could be an indication of hypoalbuminemia (Altman, 1979), which corroborates the report of Bowes et al. (1989) who documented that albumin level will not increase when the protein intake did not exceed the amount required for growth and maintenance. The birds were 21 days old, with one week for their adaptation period, and, as such, they need more protein for growth and maintenance. According to Bell (1971), total protein is influenced by breed, age, environment, physiological state, and sex. The results of 
the total protein and albumin obtained from this study is consistent with the findings of Mitruka and Rawnsley (1981) and Ross et al. (1976), who stated that the total protein and albumin level is lower in younger birds.

The ALT, AST, and the ALP values of the treated birds were found within the normal range given by Mitruka and Rawnsley (1977). Though a slight increase in the value of AST was observed which follows the inclusion level of the bovine testicular fluid of the treated birds, with T5 $(100 \mathrm{ml} / \mathrm{L}$ of the crude testosterone) birds having the highest expression of the liver enzyme (204.40 iu/l). The absence of abnormal rise of AST in the bloodstream of treated birds suggests that the bovine testicular fluid administered to the birds did not cause liver or other organ damage. The Alkaline phosphatase fell within the range of Mitruka and Rawnsley (1977), though the expression of this liver enzyme did not follow a regular pattern. The normal value of these liver enzymes may indicate that the organs of the treated birds were not stressed or damaged and the inclusion of the bovine testicular fluid in the drinking water of the treated birds did not have any adverse effect on the health status of the birds. Besides, the expression of the creatinine enzyme in the serum of the treated birds further indicated there were no abnormal changes in the serum levels of creatinine kinase (CK) or creatinine phosphate kinase (CPK) in the kidney, liver and heart of the treated birds.

The cholesterol values obtained was above the upper limit of the reference range given by Mitruka and Rawnsley (1977). Although there was no significant difference between the treated group and the control which suggests that the inclusion of the testicular fluid in the drinking water of the birds did not have any negative effect on the lipid profile or cholesterol level of the treated birds as it competes favourably with the control (Matsumoto, 2002).

The serum biochemical parameters at day 49 revealed no significant difference among the treatment groups except for the alkaline phosphate and total protein. The activities of the liver enzyme are relatively low, but increases rapidly in the blood following muscle or liver damage. However, the increase in the total protein is an indication of proper utilization of dietary protein possibly stimulated by crude testosterone in the testicular fluid.

Testosterone or one of its physiologically active metabolites binds to receptors in muscle and stimulates increased incorporation of amino acids into protein, which also agrees with the findings of Ross et al. (1979), who found that the total protein and globulin increased for the first eight weeks in leghorn chickens. Though the values obtained were still below the recommended range reported by Mitruka and Rawnsley (1977) and Wikivet (2012), but the results obtained suggest that the inclusion of bovine testicular fluid tends to increase the expression of the total protein in serum of the treated birds than the control birds, which may probably help in the production of antibody to fight diseases and infections.

The AST and ALP that were within the reference range of Mitruka and Rawnsley (1977) suggest that the increase in the testicular fluid that contained crude testosterone did not affect the specific and non-specific liver enzyme. The AST and ALT values obtained in this present research for birds at day 49 were within the recommended range by Mitruka and Rawnsley (1977) except the AST of the birds administered $100 \mathrm{ml} / \mathrm{L}$ which exceeded the upper limit. This suggests that higher bovine testicular fluid may have possibly impaired the kidney and/or liver (Nishino, 1975; Hadelsman and Gupta, 1997; Filova et al., 2013).

There was no significant difference in the values obtained for the creatinine across the treatment group. However, as the bovine testicular fluid increased across the treatments, there was a slight increase in the creatinine levels, although the values obtained were low compared to the report of Mitruka and Rawnsley (1977) and WikiVet (2012). The low creatinine values could also suggest that there was a decrease in muscle metabolism. Low muscle mass is associated with low creatinine levels (Sissons, 2017). The cholesterol levels obtained were found to increase with the inclusion levels of the bovine testicular fluid. The level in the birds administered $0 \mathrm{ml} / \mathrm{L}$ and $25 \mathrm{ml} / \mathrm{L}$ were within the recommended range, but those that received 50, 75 and $100 \mathrm{ml} / \mathrm{L}$ testicular fluid, respectively, were above the range reported by Mitruka and Rawnsley (1977), which implies that there is a tendency the crude testosterone in the testicular fluid possibly precipitate an increase in cholesterol.

The haematological parameters examination is among the methods which may contribute to the detection of some changes in health and physiological status, which may not be apparent during physical examination, but which affects the fitness of the animal (Bamishaiye et al., 2009). On day 21 , the bovine testicular fluid did not affect the health status of the treated since they compare favourably with the control birds. The values obtained for most of the haematological variables were within the recommended physiological range by Mitruka and Rawnsley (1977), which suggest that the bovine testicular fluid did not have any side effect on all the haematological parameters of the birds probably the birds were still acclimatizing to the test ingredient. Conversely, it was observed that there was a slight increase in the haematological parameters of the birds at 49 days of age. This suggested that the bovine testicular fluid did not have any adverse effect on the blood level of the treated birds neither did they suffer from anaemia. Though the result obtained were not significantly different among the treatments, but agreed with the report of Zhao et al. (2013) who found that testosterone showed a tendency to increase HB, PCV level at 6 weeks, and lowered blood viscosity in rabbits.

The addition of natural growth promoters to feeds or water of poultry or farm animals may have several beneficial effects, including the rapid development of a healthy gut microflora stabilization of digestion, increased growth performance, stimulation and rapid maturation of the immune system, reduced incidence of diarrhea, improved feed efficiency, lower mortality rates (Pasteiner, 2006). It is assumed that an increase in villus height is 
paralleled by an increase in digestive and absorptive function of the intestine due to an increase of surface area, expressive of brush border enzymes and nutritional transport system (Pluske et al., 1996). Larger villus height is an indicator of intestinal villi activity (Langhout et al., 1999; Shamoto and Yamauchi, 2000). Long villi are usually associated with excellent gut health, increased absorptive efficiency and healthier GIT (Alfaro et al., 2007). According to Cera et al. (1988), well-developed enterocytes and longer villus height with a large capacity of the luminal area provide maximum absorption and digestion. According to the report of Ravindran et al. (1984) and Apajalahti et al. (2004), the gut microfloral can reduce the nutrient uptake of the host animal by increasing the thickness of the gastro intestinal tract and also caused an increase in the rate of digesta passage. This will in turn increase the rate of turn-over of the gut mucosa by paving way for the gut microflora to compete with the host for a portion of dietary energy and protein released from the feed. It was observed that the birds had the highest intestinal weight and length compared to other treatments group, which corroborates the report of intake of exogenous feed is accompanied by the rapid development of the GIT and associated organs. It was observed that the treated birds grow rapidly than the control birds (Ewuola and Olujimi, 2019) due to the development of the ileum absorptive cell possibly induced by the bovine testicular fluid. In addition, the development of the intestinal mucosa of the birds was found to follow the trend of the increase in the inclusion level of the bovine testicular fluid administered to the birds. Birds administered $100 \mathrm{ml}$ of bovine testicular fluid/liter of water was found to have the highest intestinal mucosal development which enhanced the rate of nutrient absorption and growth performance than the control and other treatment groups (Ewuola and Olujimi, 2019). The report of this study agreed with the finding of Miles et al. (2006) who reported that a welldeveloped intestinal morphology will improve various nutrient absorption and thereby enhance growth performance. Evidence from the report of Ulshen et al. (1993) suggests that bovine growth hormone could facilitate hyperplasia in the intestinal mucosa without depending on whether the feeding is ad libitum or restricted. This established the fact that the treated birds developed better intestinal mucosa compared to the control birds (though the treated birds and the control birds were fed ad libitum) as a result of the inclusion of the bovine testicular fluid which facilitated the development of the mucosa. This implies that the increased growth performance of the treated birds (Ewuola and Olujimi, 2019) was enhanced by the synergistic action of the androgen hormones and the nutrient released from the feed supplied to the birds which corroborates with the report of Ranaweera (1977) that in male and female turkeys, androgens hormones were found to increase the growth rate as well as feed conversion efficiency, possibly by enhancing the anabolic effect of the bovine testicular fluid.

\section{Conclusion}

The result of this study showed that bovine testicular fluid which can be easily obtained as a waste product from the abattoir can be used to enhance the feed nutrient absorptive capacity of the intestinal mucosa surface area and utilization thereby improve the growth performance of broiler chickens, the bovine testicular fluid did not have a deleterious effect on the haematological parameters as the immunity of the bird was not comprised. However, levels above $75 \mathrm{ml} / \mathrm{L}$ induce specific and non-specific enzymes and should be further investigated

\section{Recommendations}

From the result of the present study, it can be recommended that:

1. Up to $75 \mathrm{ml}$ of the bovine testicular fluid extract can be diluted in one litre of water to improve the feed nutrient digestibility and absorption level of broiler chicken and therefore enhance its growth performance.

2. Further research on levels above $100 \mathrm{ml}$ per litre of drinking water is recommended.

\section{CONFLICT OF INTEREST}

The authors declare that there is no conflict of interest.

\section{REFERENCES}

Abijo, I. D. (2017). Haematological and serum biochemical indices of matured rabbit bucks administered methanolic carrot fruit extract. M.Sc. Project, Department of Animal Science, University of Ibadan, Ibadan, Oyo, Nigeria. Pp. 35-44.

Adejinmi, O. O., Williams, T. J., Odetola, O. M., Ngozi, O., Abioja, M., O., \& Ojezele, G. (2015). Growth, performance and carcass yield of broilers fed standard and low protein feeds with inclusion of dietary crude testosterone. International Journal of Biology, 7(9), 138-143.

Alfaro, D. M., Silva, A. V., Borges, S. A., Maiorka, F. A., Vargas, S., \& Santin, E. (2007). Use of Yucca schidigera extract in broiler diets and its effects on performance results obtained with different coccidiosis control methods. Journal of Applied Poultry Research, 16(2), 248-254.

Altman, R. B. (1979). Avian clinical pathology, radiology, parasitic and infectious diseases. Proceedings of American Animals Association. South Bend, Indiana.

Annamaria, P. (2012). Steroid hormones in food producing animals: A bird's-eye view of veterinary medicine. In: PerezMarin, C. C. (ed.). IntechOpen. Retrieved from https://www.intechopen.com/books/a-bird-s-eye-view-ofveterinary-medicine.

Apajalahti J., Kettunen, A., and Graham H., 2004. Characteristics of gastrointestinal microbial communities, with special reference to the chicken. World's Poultry Science Journal, 60(2), 223-232.

Bamishaiye, E. I., Muhammad, N. O., \& Bamishaiye, O. M. (2009). Haematological parameters of albino rats fed on tiger nuts (Cyperus esculentus) tuber oil meal-based diet. The 
International Journal of Nutrition and Wellness, 10(1), 5p.

Bell, D. J. (1971). Plasma enzymes. In: Bell, D. J., Freeman, B. M. (eds.). Physiology and biochemistry of the domestic fowl. Academic Press Inc., London. p. 964.

Bowes, V. A., Julian, R. J., \& Stirtzinger, T. (1989). Comparison of serum biochemical profiles of male broilers with female broilers and White Leghorn chickens. Canadian Journal of Veterinary Research, 53(1), 7-11.

Cera, K. R., Mahan, D. C., Cross, R. F., Reinhart, G. A., \& Whitmoyer, R. E. (1988). Effect of age, weaning and postweaning diet on small intestinal growth and jejunal morphology in young swine. Journal of Animal Science, 66(2), 574-584.

Djolai, M., Somer, L., Damjanov, D., Hadnadjev, L., \& Krnojelac, D. (1998). Volume density of intestinal glands in clinical remission of ulcerative colitis. Folia Anatomica, 26(Suppl 1), 56-57.

Egbunike, G. N., Williams, J. T., \& Agiang, E. S. (2008). Utilization of crude testis extract to enhance broiler production in the humid tropics. Global Journal of Agricultural Sciences, 7(1), 27-30.

Ewuola, E. O., \& Egbunike, G. N. (2008). Haematological and serum biochemical response of growing rabbit bucks fed dietary fumonisin B1. African Journal of Biotechnology, 7(23), 4304-4309.

Ewuola, E. O., \& Olujimi, A. T. (2019). Bovine testicular fluid enhanced growth performance of broiler chickens. Nigerian Journal of Animal Production, 46(1), 188-195.

Ewuola, E. O., Amadi, C. U., \& Imam, T. K. (2011). Performance evaluation and nutrient digestibility of rabbits fed dietary prebiotics, probiotics and symbiotics. International Journal of Applied Agriculture and Apiculture Research, 7(1), 107-117.

Filova, B., Ostantnikova, D., Celec, P., \& Hodosy, J. (2013). The effect of testosterone on the formation of brain structures cell tissue organs. Medical and Science Publishers 197(3), 169-77.

Forlan, R. L., Macari, M., Malheiros, R. D., Moraes, V. M. B., \& Malheiros, E. B. (1999). Effect of age and strain on haematology and blood-biochemical parameters in broiler chickens. Revista Brasileira de Ciencia Avicola, 1(2), 117-122.

Hadelsman, D. J., \& Gupta, L. (1997). Prevalence and risk factors for anabolic-androgenic steroid abuse in Australian high school students. International Journal of Andrology, 20(3), 159-164.

Hughes P., \& Heritage, J. (2004). Antibiotic growth-promoters in food and animal. FAO Animal Production and Health Paper, Pp. 129-152.

Kitt, S., Miller, P., \& Lewis, A. (2001). Factors affecting small intestine development in weanling pigs. Nebraska Swine Report. Retrieved from https://digitalcommons.unl.edu/cgi/viewcontent.cgi $?$ article $=10$ 98\&context=coopext swine.

Langhout, D. J., Schutte, J. B., Van Leeuwen, P., Wiebenga, J., \& Tamminga, S. (1999). Effect of dietary high-and lowmethylated citrus pectin on the activity of the ileal microflora and morphology of the small intestinal wall of broiler chicks. British poultry science, 40(3), 340-347.

Matsumoto, A. M. (2002). Andropause: clinical implications of the decline in serum testosterone levels with aging in men. The Journals of Gerontology Series A: Biological Sciences and Medical Sciences, 57(2), M76-M99.

Miles, L., Newton, A. C., DeFries, R. S., Ravilious, C., May, I., Blyth, S., Kapos, V., \& Gordon, J. E. (2006). A global overview of the conservation status of tropical dry forests. Journal of biogeography, 33(3), 491-505.

Mitruka, B. J., \& Rawnsley, H. M. (1981). Clinical biochemical and haematological reference values in normal experimental animals (2nd edition). Masson Publishing U.S.A Inc. Pp. 186187.

Mitruka, B. M., \& Rawnsley, H. M. (1977). Clinical biochemical and hematological reference values in normal experimental animals. USA: Masson Publishing Inc. (pp.134-135).

Muthusamy, T., Murugesan, P., Srinivasan, C., \& Balasubramanian, K. (2011). Sex steroids influence glucose oxidation through modulation of insulin receptor expression and IRS-1 serine phosphorylation in target tissues of adult male rat. Molecular and Cellular Biochemistry, 352, 35-45.

Nishino, Y. (1975). Effects of androgens and related steroid on liver functions and enzymes. Pharmacol Therapeutics Journal. 1(2), 189-207.

Olafedehan, C. O., Obun A. M., Yusuf, M. K., Adewunmi, O. O., Oladefedehan A. O., Awofolaji A. O., \& Adeniji, A. A. (2010). Effects of residual cyanide in processed cassava peal meals on haematological and biochemical indices of growing rabbits. Proceedings of 35th Annual Conference of Nigerian Society of Animal Production, p. 212.

Pasteiner, S. (2006). New natural concept for poultry gut health. International Poultry Production, 14(1), 17.

Pluske, J. R., \& Williams, I. H., (1996). Reduce stress in piglets as a means of increasing production after weaning: administration of amperozide or co-mingling of piglets during lactation. Animal Science 62(1), 121-130.

Ranaweera, K. N. P. (1977). The Effects of Trienbolone Acetate in growing Turkeys (Doctoral dissertation, University of Cambridge).

Ravindran, V., Kornegay K. E., \& Webb J. R. (1984). Effect of fibre and virginiamycin on nutrient absorption, nutrient retention and rate of passage in growing swine. Journal of Animal Science, 59(2), 400-408.

Ross, J. G., Christie, G., Halliday, W. G., \& Jones, R. M. (1976). Determination of haematology and blood chemistry values in healthy six-week old broiler hybrids. Avian Pathology, 5(4), 273-281.

SAS (1999). Statistical Analytical System (Version 9.1). SAS Institute Incorporation, Cary, NC, USA.

Scheuer P.J., and Chalk B.T., (1986). Clinical tests: Histopathology. The journal of Pathology, 152(4), 340-468.

Shamoto, K., \& Yamauchi, K. (2000). Recovery responses of chick intestinal villus morphology to different refeeding procedures. Poultry Science, 79(5), 718-723.

Sissons, C. (2017). Low creatinine levels: Causes, symptoms, and treatments. Retrieved 27th February, 2019 from www.medicalnewstoday.com/articles/319892.php.

Ulshen, M. H., Dowling, R. H., Fuller, C. R., Zimmermann, E. M., \& Lund, P. K., (1993). Enhanced growth of small bowel in transgenic mice overexpressing bovine growth hormone. Gastroenterology, 104(4), 973-980.

WikiVet English (2012). Chicken biochemistry. Retrieved 4th March, 2019 from https://en.wikivet.net/Chicken Biochemistry.

William, T., Wyss, M., Bridezka, D., Nicolay, K., \& Eppenberge, H. M. (1992). Intracellular compartmentation, structure and function of creatine kinaseiso enzyme in tissue with high and fluctuating energy demands: The phosphocreatine circuit for cellular or energy homeostasis. The Biochemical Journal, 281(1), 21-40.

Zhao, C., Moon, D. G., \& Park, J. K. (2013). Effect of testosterone on undecanoate on haematological profiles, blood lipid and viscosity and plasma testosterone level in castrated rabbits. Canadian Urological Association Journal, 7(3-4), E221-E225. 